\title{
Application of A Tank Model to Assess the Performance of Rotiklot Reservoir Initial Filling
}

\author{
Denik Sri Krisnayanti ${ }^{1}$, Andi H. Rizal ${ }^{1}$, Wilhelmus Bunganaen ${ }^{1}$, \\ Costandji Nait ${ }^{2}$, Anang G. A. D. Mangu ${ }^{1 *}$ \\ ${ }^{1}$ Department of Civil Engineering, Nusa Cendana Universitas, Kupang, INDONESIA \\ Jalan Adi Sucipto Penfui Kupang \\ ${ }^{2}$ Department of Water Resources, Brawijaya University, Malang, INDONESIA \\ Jalan MT. Haryono No. 167 Malang \\ *Corresponding authors: ananganargi@gmail.com
}

SUBMITTED 15 May 2019 REVISED 21 August 2019 ACCEPTED 12 November 2019

\begin{abstract}
Rotiklot dam is located in Belu Regency that has the tropic climate, with very short wet season (4-5 months) and a very long dry season (7-8 months). The average monthly rainfall in December - April of approximately $300-500 \mathrm{~mm} / \mathrm{month}$, while in another month only ranges $30-60 \mathrm{~mm} / \mathrm{month}$. During the rainy season, rainwater will overflow as surface water and collect in the river as a flood toward the sea. The construction of a dam is one alternative to overcome the water needs of the community during the dry season. The Rotiklot dam retains the flow of water in the Motamuru River and its reservoir can accommodate 2.9 million $\mathrm{m}^{3}$. Impounding is a process carried out once a dam has been constructed. It is a comprehensive process involving filling time and water inflow. The purpose of this study was to determine the first filling time and the inflow volume in Rotiklot Reservoir in the years of dry, low, normal and sufficient water using the Tank method. It aimed to simulate the initial filling of the reservoir. Also, the study is expected to evaluate the most suitable Tank model, with parameters calibrated using the Genetic Algorithm optimization approach. The determination coefficient using a four series tank is 0.531 greater than the coefficient obtained from 3 series tank simulation, which was 0.506 . The total inflow volume in Rotiklot Reservoir for dry, low, normal and sufficient were 1.946, 7.289, 9.699, 13.822 million $\mathrm{m}^{3}$ respectively. Based on the calculation result of the inflow volume of the year of the low water, the filling time is around three months, starting from mid-December to mid-March.
\end{abstract}

KEYWORDS Genetic Algorithm; Initial Filling; Inflow Discharge; Rotiklot Reservoir; Tank Model.

(c) The Author(s) 2020. This article is distributed under a Creative Commons Attribution-ShareAlike 4.0 International license.

\section{INTRODUCTION}

Belu Regency of East Nusa Tenggara Province has a dry climate with very short rainy and long dry seasons ranging from December-March and April-November, respectively. The rainy days per year amounts to 40 . The region experiences relatively short wet season with mountainous topography and rare vegetation. Consequently, there is a small rainfall average of \pm 1.500 $\mathrm{mm}$ /year, leading to water deficiency. This affects food-crops production, such as palawija/rice (BPS Kab.Belu, 2018). The government needs to address the issue of water deficiency with concrete and long-term plans. In response to this problem, the Rotiklot Dam in the Fatuketi Village of Kakuluk Mesak District was constructed. The dam retains the flow of water in the Motamuru River, which has a length of $6.6 \mathrm{~km}$, with 11.69 $\mathrm{km}^{2}$ watershed area. It was designed with a storage capacity of 2.9 million $\mathrm{m}^{3}$ and expected to provide several benefits, including irrigation to an area of 139 hectares and a secondary crop of 500 hectares. It is also supposed to control floods in flood-prone areas, apart from providing domestic water to the people of Belu Regency especially the Fatuketi Village community (Balai Besar Wilayah Sungai NT II, 2012). 
The construction of the dam involved several stages, including preparation, development planning, as well as construction and impounding. The initial filling is carried out after construction work is completed and it is the most critical phase (Regulation 37,2010). In this stage, the amount of inflow into the inundation area is very essential. If the inflow is small, the initial filling time is long and can cause drought downstream (Amaral and Biligardo, 2018).

\section{METHODS}

\subsection{Location Research}

As shown in Figure 1, Rotiklot Dam is located in Fatuketi Village, Kakuluk Mesak District, Belu Regency, on the $9^{\circ} 4^{\prime} 1.82^{\prime \prime S}$ and $124^{\circ} 50^{\prime} 11.33^{\prime \prime E}$ coordinates. It is an earth-fill dam, approximately $8.74 \mathrm{~km}$ from the center of Atambua and the river length of $6.6 \mathrm{~km}$ with an area of $11.69 \mathrm{~km}^{2}$ (Balai Besar Wilayah Sungai NT II, 2012).. The study was conducted for approximately 1 (one) year, starting from May 2018 to April 2019.

\subsection{Procedures and Analysis}

This study uses quantitative methods, which involve developing mathematical models. This requires linking a natural phenomenon in observation with calculations that represent the data as follows (Figure 2).
1. Calculate the amount of half-monthly rainfall

2. Calculate the potential evapotranspiration (KP-01, 2013)

3. Calculate observation discharges with tank models 1994-1996

4. Simulation discharge calibration with observation discharge of 1994-1996

5. Calculate the time needed to fill the Rotiklot Reservoir until it reaches the planned storage volume.

Analysis of the secondary data include:

1. Hydrological data

a. Rainfall data of 25-years (1992 to 2016) from the Atambua Rainfall Station.

b. Climatology data of 25-years (1992 to 2016) obtained from Meteorological, Climatological and Geophysical Agency (BMKG) Lasiana Station.

c. Observation discharge data of Oesao River from Automatic Water Level Recorder (AWLR) 1994 to 1996. Oesao River is located $163.41 \mathrm{~km}$ from Motamuru River Basin. The object of observation data was from the Oesao River due to the unavailability of discharge data in the surrounding catchment area as a comparison.

2. The technical data of the dam was obtained from Balai Wilayah Sungai (BWS) of Nusa Tenggara II as shown in Table 1.

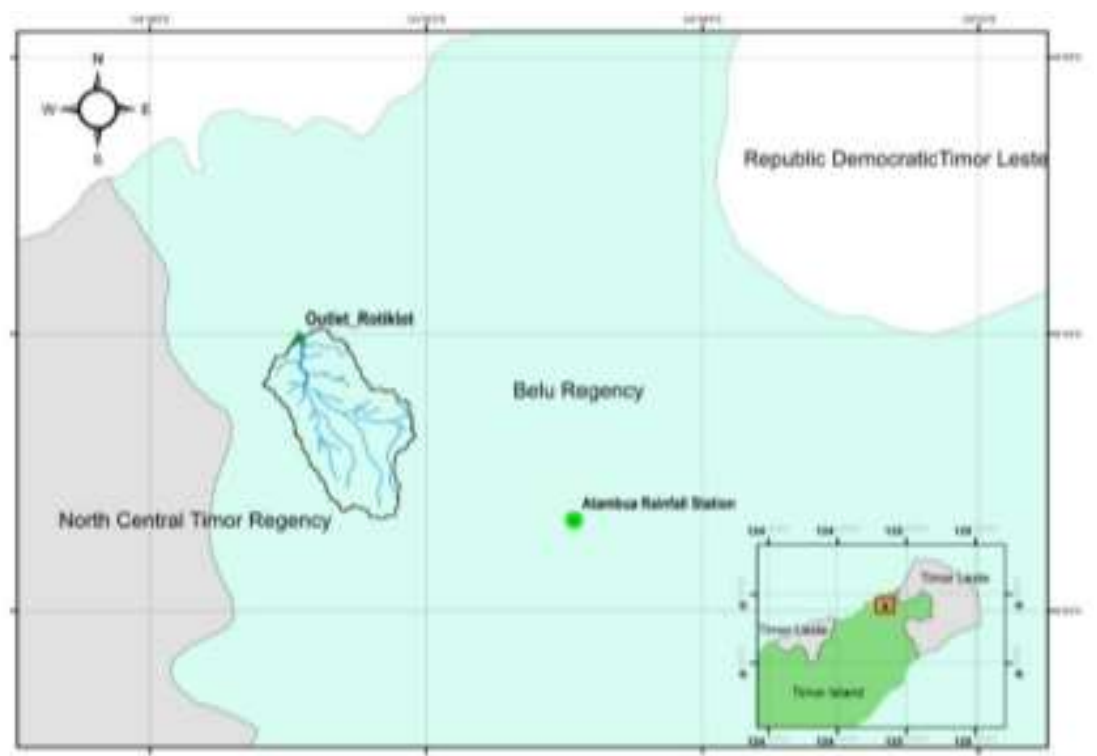

Figure 1. Rotiklot Reservoir Location(Google Earth, 2018) 


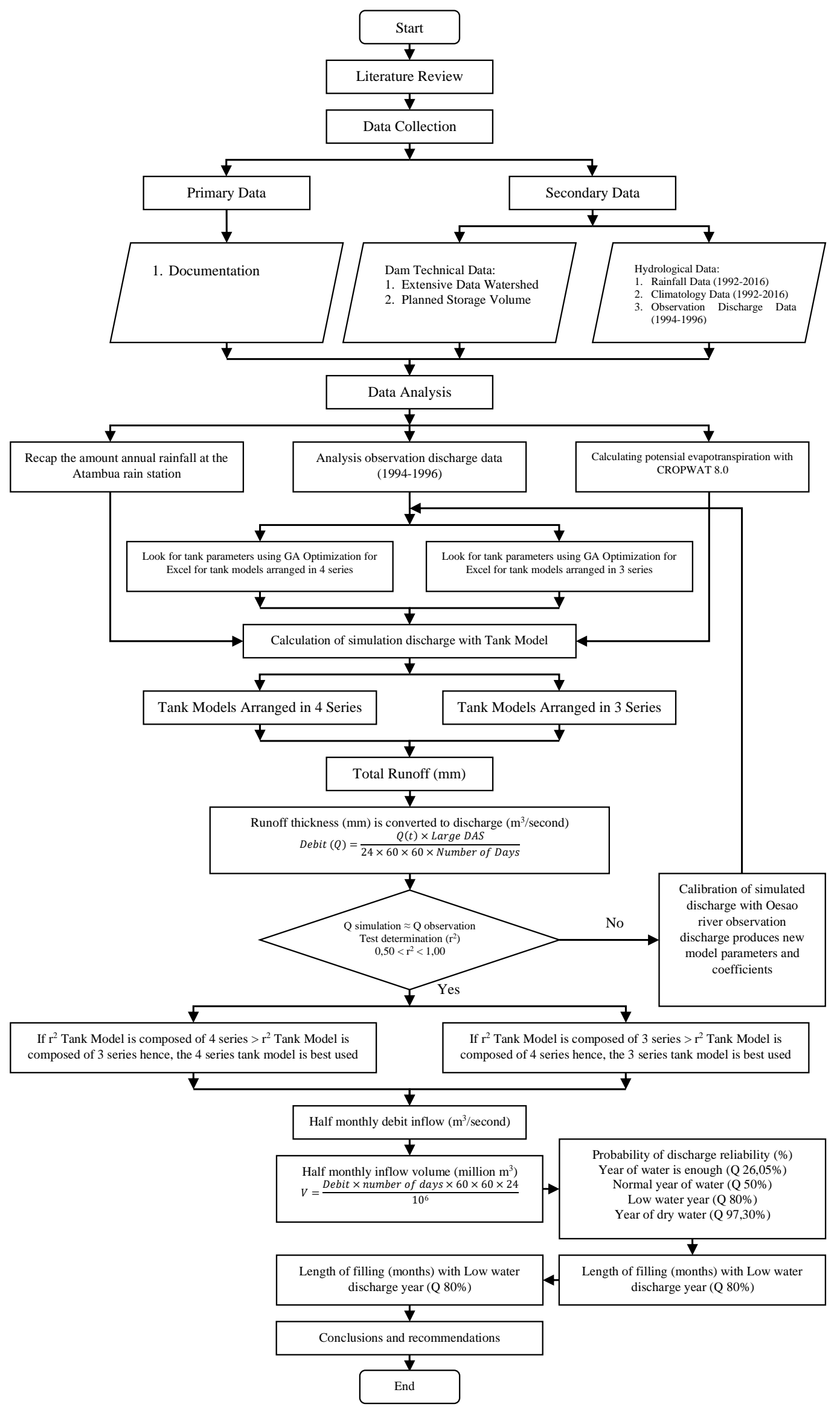

Figure 2. Research Flowchart 
Table 1. Technical Data of Rotiklot Dam

\begin{tabular}{lll}
\hline No & Parameter (unit) & Magnitude (Remarks) \\
\hline 1 & Catchment area & $11.69 \mathrm{~km}^{2}$ \\
2 & River length & $6.6 \mathrm{~km}$ \\
3 & Maximum water level elevation & $+54.8 \mathrm{~m}$ \\
4 & Minimum water level elevation & $+52.5 \mathrm{~m}$ \\
5 & Storage volume & $2.9 \mathrm{million} \mathrm{\textrm {m } ^ { 3 }}$ \\
6 & Inundation area & $22.5 \mathrm{ha}$ \\
7 & Dam & \\
& 7.1 Type & Zonal heap with sloping core \\
7.2 Peak length & $142.71 \mathrm{~m}$ \\
7.3 Maximum height & $15.00 \mathrm{~m}$ \\
7.4 Peak elevation & $+55.50 \mathrm{~m}$ \\
& 7.5 Freeboard (Q1000) & $0.70 \mathrm{~m}$ \\
7.6 Upstream slope & $1: 3.00$ \\
7.7 Downstream slope & $1: 2.50$ \\
Spillway & \\
8.1 Location & Right side \\
8.2 Geology & Weathered claystone \\
8.3 Design flood (Q1000) & $329.79 \mathrm{~m}^{3} / \mathrm{sec}$ \\
8.4 Type & Front spillway without door \\
8.5 Crest length & $30.00 \mathrm{~m}$ \\
Intake & \\
9.1 Type & Pipes with setting door in downstream \\
9.2 Capacity & $0.196 \mathrm{~m}^{3} / \mathrm{second}$ \\
9.3 Pipes outlet & $250.00 \mathrm{~mm}$ \\
\hline & &
\end{tabular}

\section{RESULTS}

\subsection{Rainfall Data Analysis}

Rainfall data in BMKG Lasiana Station was processed half-monthly from 1992-2016. The data was from the Atambua rain station since it is closer to the location of the reservoir and still within the Motamuru River Basin.

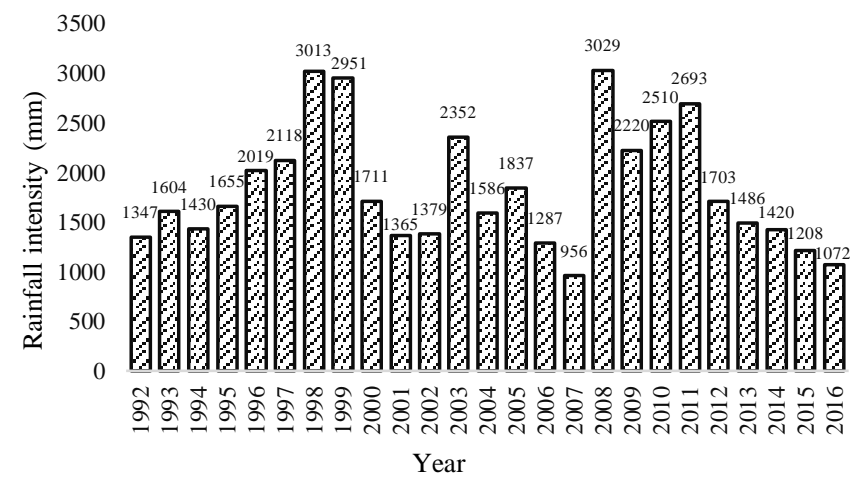

Figure 3. Atambua Station's Annual Rainfall from 1992 2016
According to data from 1992-2016 shown in Figure 3, the maximum annual rainfall value in Atambua was recorded in 2008, specifically 3,029 $\mathrm{mm}$, while the minimum was in 2007 which was $956 \mathrm{~mm}$.

\subsection{Evapotranspiration Data Analysis}

Potential evapotranspiration is critical in determining the discharge of the Tank model. It was calculated using CROPWAT 8.0 program. This is a decision support system developed by the FAO Division of Land and Water Development based on the Penman-Monteith method to plan and regulate irrigation. 


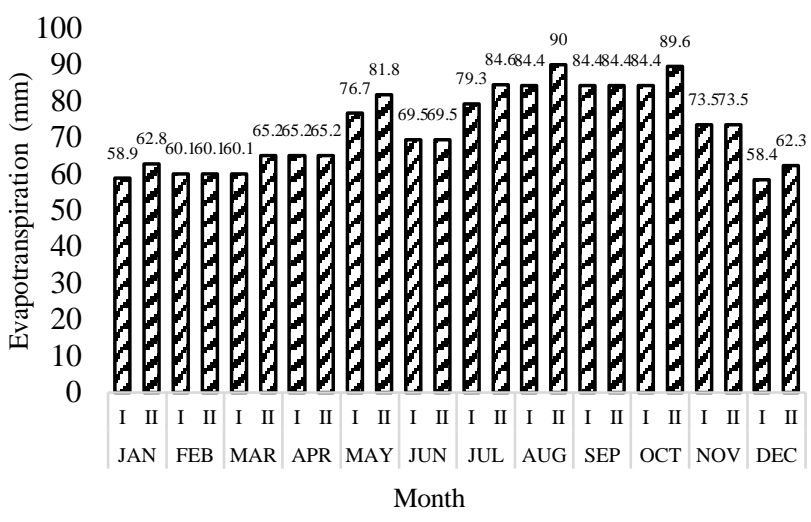

Figure 4. Half-Monthly Evapotranspiration

In Figure 4, the maximum monthly evapotranspiration was recorded in the second part (II) of August, precisely $90.0 \mathrm{~mm}$. The minimum was in the first part (I) of December with $58.4 \mathrm{~mm}$ and the average of evapotranspiration in the Motamuru watershed was $72.7 \mathrm{~mm}$.

\subsection{The Tank Model Structure}

The Tank model is one of the rainfall-runoff simulations that introduced by Sugawara and Funiyuki (1956) and is widely used in Indonesia. The tank model is a simple structure but an efficient and powerful tool in rainfall-runoff simulation and verification.

\subsubsection{Equation of original tank model}

Tank Model is grouped into two parameters, including 1) outlet hole coefficient parameter on the side of the wall and the bottom of the tank and 2 ) groundwater storage parameters (Kuok, et al., 2011). The total outflow from the outlet on the side (Q) shows the accumulation of water flow from the system in the watershed based on Equation (1).

$Q(t)=Q a 1(t)+Q a 2(t)+Q b(t)+Q c(t)+Q d(t)$

Where $Q a 1(t)$ and $Q a 2(t)$ are the run-off value at the first and second outlet in tank 1 respectively.
$Q b(t)$ and $Q c(t)$ are the run-off value at tank outlet 2 and 3 respectively.

The tank model simulates rainfall at a time $P(t)$ which then fills up tank I. The collected water flows through holes in the right wall or seeps through holes in the bottom, filling tank II. Similarly, Water collected in tank II flow through holes in the right wall and enter the tank III. The downward infiltrated water stabilizes the groundwater and flows slowly out of the aquifer (Suryoputro and Nugroho, 2018). This process repeats until the last tank is filled (Figure 5, 6).

$$
\begin{aligned}
& H a(t+1)=H a(t)+P(t)-Q a 1(t)-Q a 2(t)-I a(t) \\
& H b(t+1)=H b(t)+I a(t)-Q b(t)-I b(t) \\
& H c(t+1)=H c(t)+I b(t)-Q c(t)-I c(t) \\
& H d(t+1)=H d(t)+I c(t)-Q d(t)
\end{aligned}
$$

In Equation (2) $\mathrm{Ha}(t+1)$ is the reservoir in tank 1, $H a(t)$ is the initial storage in tank $1, Q a 1(t)$ and Qa2(t) are run-offs at the first and second outlet in tank 1 respectively, while $I a(t)$ is the infiltration. In Equation (3), $H b(t+1)$ is a basin in tank 2, $H b(t)$ is the initial storage, $Q b(t)$ is run-off at outlet 2 , and $I b(t)$ is the infiltration. In Equation (4), $H c(t+1)$ is reservoir in tank 3, $H c(t)$ is Initial storage, $Q c(t)$ is run-off at outlet 3 , and $I c(t)$ is infiltration. In Equation $(5), H d(t+1)$ is reservoir in tank $4, H d(t)$ is initial storage value, and $Q d(t)$ is runoff value. In this study, two tank models were used, specifically 3 and 4 series.

\subsubsection{The 3-series arranged tank model}

This model consists of 3 tanks arranged vertically. The row of tanks is shown in Figure 5. In Figure 5, ETO is evapotranspiration, $\mathrm{Cia}, \mathrm{Cib}$, and $\mathrm{Cic}$ are the Infiltration coefficients in Tank 1,2, and 3, respectively. Da1and Da2 is the height of surface flow outlet 1 and 2, respectively. $D b 1$ and $D b 2$ are heights of intermediate outlet-1 and 2, while $D c 1$ and $D c 2$ are the heights of sub-base flow outlets 1 and 2 respectively. 


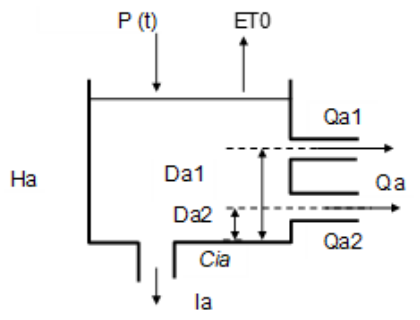

Tank 1

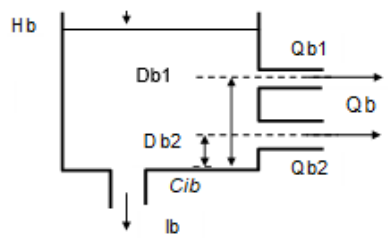

Tank 2

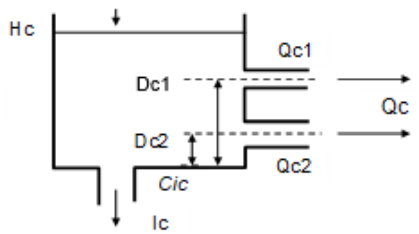

Tank 3

Figure 5. Rows of Modified 3-Series Tank Model

\subsubsection{The 4-series arranged tank model}

This tank model consists of 4 pieces of tanks arranged vertically. The row of tanks from this tank model can be seen in Figure 6.

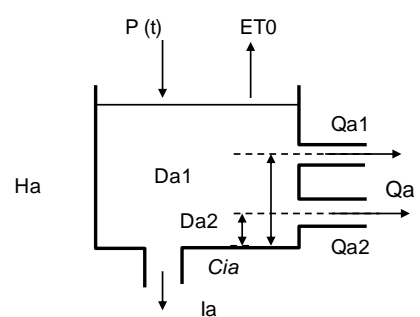

Tank 1

$\mathrm{Hb}$
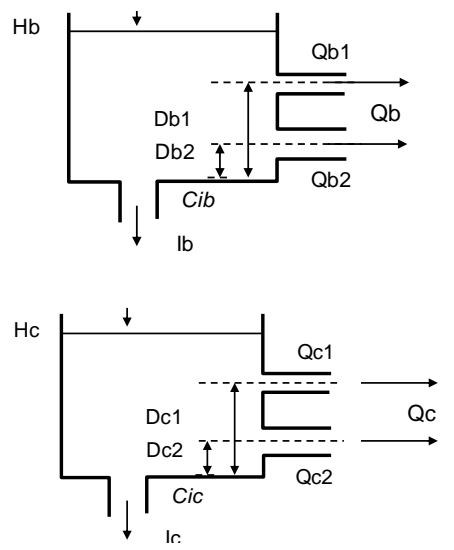

Tank 3

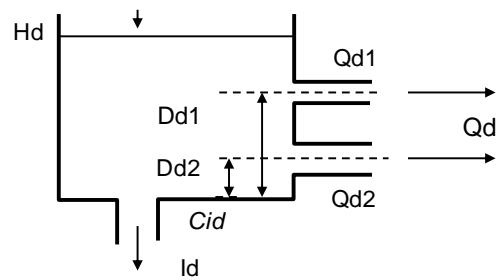

Tank 4

Figure 6. Rows of Modified 4-Series Tank Model
Where Cid is infiltration coefficient in Tank-4, Dd1 and $D d 2$ are the heights of base flow outlet- 1 and outlet-2

\subsection{The Tank Model Parameters Calibration Using Genetic Algorithm (GA) Optimization Method}

Genetic Algorithm (GA) was discovered by John $\mathrm{H}$. Holland of the University of Michigan who began his research in 1960 (Berlianty and Aridfin, 2010). In the previous calculation, the determination coefficient $\left(r^{2}\right)$ has not fulfilled the requirements of $0.50 \leqslant r^{2} \leqslant 1.00$ for satisfying $r^{2}$ values (Silva, et al., 2015). Therefore, a Genetic Algorithm Optimization for Excel software is used as shown in Figure 6. The software uses an excel spreadsheet as a link to display results. In the function section, the optimization is selected from the drop-down in the design variable. It is then entered into the cell excel link which displays the new parameters and provides realistic boundaries between the lower and upper limits. This is in line with Setiawan and Rudiyanto (2003) and JICA (2003). The constraints section is selected as the boundary used for the new parameters to be searched ("less or equal $\leq$ ", "greater or equal $\geq$ " or "exactly equal ="). Once all the settings are filled, the Run GA tab is selected before clicking Run. The software runs an iterative process to determine new and more optimal parameters. In this study the search for new parameters is conducted twice, for 3 and 4 Series Arranged tank models.

\subsubsection{The 3-series arranged tank model}

Table 2 shows the results of GA optimization for 3- series arranged tank models. Once the parameters are re-calibrated using the GA Optimization for Excel software, the new determination coefficient of $r^{2}$ is 0.506 . It is acceptable in case $0.50 \leqslant r^{2} \leqslant 1.00$.

\subsubsection{The 4-series arranged Tank Model}

Table 3 shows the results of GA optimization for 4-Series arranged tank models. After recalibrating the new parameters using the GA 
Optimization for Excel software, the new determination coefficient of $r^{2}$ is obtained at 0.531 . The value of $r^{2}$ determination coefficient for the 4-series tank model is much larger than the tank model arranged in 3-series. Therefore, for the next calculation, a 4-tank model is used series.

Table 2. Value of Coefficients and Parameters Results of GA Optimization for Excel for 3- Series Arranged Tank Models

\begin{tabular}{llllll}
\hline Tank 1 & \multicolumn{3}{c}{ Tank 2 } & \multicolumn{2}{c}{ Tank 3 } \\
\hline$H a$ & 0.000 & $H b$ & 0.085 & $H c$ & 2650 \\
Da1 & 60.000 & $D b 1$ & 0.000 & $D c 1$ & 0.000 \\
CQa1 & 0.000 & CQb1 & 0.000 & CQc1 & 0.000 \\
Da2 & 15.000 & Db2 & 30.000 & Dc2 & 0.000 \\
CQa2 & 0.082 & CQb2 & 0.030 & CQc2 & 0.006 \\
CIa & 0.045 & CIb & 0.010 & CIc & 0.000 \\
\hline
\end{tabular}

Table 3. Value of Coefficients and Parameters Results of GA Optimization for Excel for 4-Series Arranged Tank Models

\begin{tabular}{llllllll}
\hline Tank 1 & & Tank 2 & \multicolumn{3}{c}{ Tank 3 } & Tank 4 \\
\hline Ha & 0.000 & $H b$ & 0.000 & $H c$ & 908.838 & Hd & 2950.274 \\
Da1 & 60.000 & Db1 & 0.000 & Dc1 & 0.000 & Dd1 & 0.000 \\
CQ 11 & 0.000 & CQb1 & 0.000 & CQc1 & 0.000 & CQd1 & 0.000 \\
Da2 & 15.000 & Db2 & 30.000 & Dc2 & 0.000 & Dd2 & 0.000 \\
CQ a 2 & 0.090 & CQb2 & 0.090 & CQc2 & 0.001 & CQd2 & 0.003 \\
CIa & 0.060 & CIb & 0.020 & CIc & 0.002 & CId & 0.000 \\
\hline
\end{tabular}

Table 4. Results of Calibration of Simulated Discharge and Observed Discharge in 1994-1996

\begin{tabular}{llll}
\hline Year & Month & Simulation discharge $(\mathrm{Qs})$ in $\mathrm{m}^{3} / \mathrm{sec}$ & Observation discharge $(\mathrm{Q} o) \mathrm{in} \mathrm{m}^{3} / \mathrm{sec}$ \\
\hline 1994 & January & 1.38 & 0.44 \\
& February & 2.46 & 1.43 \\
& March & 2.53 & 2.09 \\
& April & 2.07 & 4.90 \\
& May & 1.22 & 1.40 \\
& June & 1.11 & 1.46 \\
& July & 1.03 & 1.22 \\
& August & 0.99 & 1.11 \\
& September & 0.99 & 0.31 \\
& October & 0.92 & 0.00 \\
& November & 0.92 & 0.00 \\
& December & 1.20 & 0.46 \\
\hline 1995 & January & 1.95 & 1.05 \\
& February & 2.64 & 1.24 \\
March & 2.98 & 10.52 \\
April & 2.74 & 8.71 \\
May & 1.84 & 4.11 \\
& June & 1.39 & 2.83 \\
July & 1.27 & 1.82 \\
August & 1.20 & 1.49 \\
September & 1.18 & 1.28 \\
October & 1.09 & 1.22 \\
November & 1.07 & 1.09 \\
December & 2.14 & 1.29 \\
\hline
\end{tabular}


Table 5. Results of Calibration of Simulated Discharge and Observed Discharge in 1994-1996 (Cont)

\begin{tabular}{llll}
\hline Year & Month & Simulation discharge $(Q s) \mathrm{in}^{3} / \mathrm{sec}$ & Observation discharge $(\mathrm{Qo})$ in $\mathrm{m}^{3} / \mathrm{sec}$ \\
\hline 1996 & 2.12 & 3.10 \\
& January & 2.78 & 8.22 \\
& February & 3.14 & 10.31 \\
& March & 2.61 & 6.21 \\
& April & 1.78 & 4.55 \\
& May & 1.45 & 3.74 \\
& June & 1.32 & 3.37 \\
July & 1.24 & 3.40 \\
August & 1.21 & 0.09 \\
September & 1.11 & 0.07 \\
& October & 1.09 & 0.09 \\
& November & 2.16 & 3.50 \\
\hline
\end{tabular}

Based on Table 4, the volume annual error has a significant deviation $(1994=20 \%, 1995=-41.7 \%$, $1996=-52.7 \%)$. This is because the data of observed discharge from Oesao River is located quite far from the catchment area. The unavailability of observation discharge data leads to the use of discharge data from another river with similar characteristics catchment area.

\section{DISCUSSION}

The recapitulation of monthly inflow volume probabilities in the watershed of the Rotiklot Reservoir is divided into 4 season criteria (Sosrodarsono, et al., 1980). This includes the year of: 1). dry water with the total inflow into the reservoir annually, amounting to 1.9461 a reliability of $97.30 \%$ is obtained; 2 ). low water with the reliability of $75.34 \%$ is obtained, having a total inflow into the reservoir annually at 7.2898 million $\left.\mathrm{m}^{3} ; 3\right)$. normal water with the reliability of $50.68 \%$ is obtained by the total inflow into the reservoir annually at 9.6991 million $\mathrm{m}^{3} ; 4$ ). Sufficient water with the reliability of $26.02 \%$. The total inflow into the reservoir per year is 13.8217 million $\mathrm{m}^{3}$ (Table 5).

The initial filling was carried out in midDecember as shown in Table 6. Therefore, the amount of inflow volume in the Rotiklot
Reservoir is counted since then. As shown in Table 7, the time needed for initial filling in Rotiklot Reservoir is 3 months until it exceeds the capacity of the Rotiklot Reservoir, which is 2.9 million $\mathrm{m}^{3}$. The time needed for initial filling is shown in Figure 7

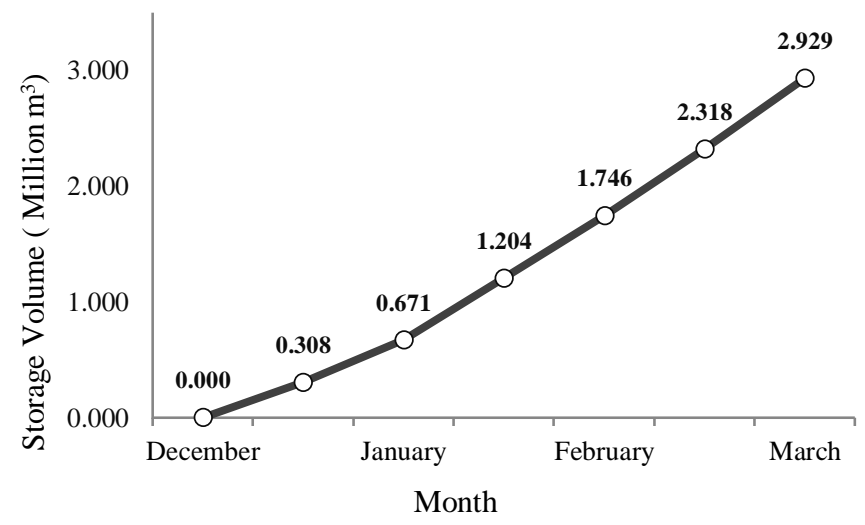

Figure 7. Length of Initial Filling in Rotiklot Reservoir

Figure 7 shows that in the first part (I) of December, the inflow volume is still zero (0). In the second part (II) it is 0.308 million $\mathrm{m}^{3}$. There is an increase in volume in the subsequent months up to the first part of March (I). The total volume of water collected is 2.929 million $\mathrm{m}^{3}$, which means that the planned storage of 2.9 million $\mathrm{m}^{3}$ at an elevation of +54.8 masl was attained. The excess water specifically 0.29 million $\mathrm{m}^{3}$ pass through the spillway at the beginning of March. 
Table 6. Results of Calibration of Simulated Runoff and Observed Runoff in 1994-1996

\begin{tabular}{|c|c|c|c|c|c|c|c|c|}
\hline \multirow{4}{*}{ Month } & \multicolumn{8}{|c|}{ Season Criteria } \\
\hline & \multirow{2}{*}{\multicolumn{2}{|c|}{$\begin{array}{l}\text { Dry Water } \\
97.30 \%\end{array}$}} & \multirow{2}{*}{\multicolumn{2}{|c|}{$\begin{array}{l}\text { Low Water } \\
75 \%\end{array}$}} & \multirow{2}{*}{\multicolumn{2}{|c|}{$\begin{array}{l}\text { Normal Water } \\
51 \%\end{array}$}} & \multirow{2}{*}{\multicolumn{2}{|c|}{$\begin{array}{l}\text { Enough Water } \\
26.02 \%\end{array}$}} \\
\hline & & & & & & & & \\
\hline & $\mathrm{m}^{3} / \mathrm{sec}$ & Million $\mathrm{m}^{3}$ & $\mathrm{~m}^{3} / \mathrm{sec}$ & million $\mathrm{m}^{3}$ & $\mathrm{~m}^{3} / \mathrm{sec}$ & million $\mathrm{m}^{3}$ & $\mathrm{~m}^{3} / \mathrm{sec}$ & million $\mathrm{m}^{3}$ \\
\hline January & 0.0796 & 0.2132 & 0.3364 & 0.9009 & 0.4281 & 1.1466 & 0.5832 & 1.5622 \\
\hline February & 0.0721 & 0.1744 & 0.4846 & 1.1723 & 0.6125 & 1.4818 & 0.9076 & 2.1956 \\
\hline March & 0.0889 & 0.2381 & 0.4460 & 1.1947 & 0.6031 & 1.6153 & 0.9100 & 2.4373 \\
\hline April & 0.0879 & 0.2277 & 0.4172 & 1.0815 & 0.5227 & 1.3548 & 0.8033 & 2.0823 \\
\hline May & 0.0591 & 0.1583 & 0.2412 & 0.6462 & 0.3552 & 0.9512 & 0.5182 & 1.3879 \\
\hline June & 0.0575 & 0.1491 & 0.1586 & 0.4110 & 0.2219 & 0.5752 & 0.3229 & 0.8369 \\
\hline July & 0.0529 & 0.1416 & 0.1261 & 0.3377 & 0.1756 & 0.4704 & 0.1994 & 0.5341 \\
\hline August & 0.0505 & 0.1353 & 0.1098 & 0.2942 & 0.1543 & 0.4133 & 0.1794 & 0.4805 \\
\hline September & 0.0488 & 0.1265 & 0.1001 & 0.2594 & 0.1411 & 0.3657 & 0.1702 & 0.4413 \\
\hline October & 0.0432 & 0.1156 & 0.0864 & 0.2315 & 0.1267 & 0.3395 & 0.1553 & 0.4160 \\
\hline November & 0.0412 & 0.1068 & 0.0851 & 0.2207 & 0.1354 & 0.3510 & 0.1564 & 0.4053 \\
\hline December & 0.0596 & 0.1596 & 0.2016 & 0.5399 & 0.2368 & 0.6343 & 0.3892 & 1.0423 \\
\hline Total & & 1.9461 & & 7.2898 & & 9.6991 & & 13.8217 \\
\hline
\end{tabular}

Table 7. The Amount of Rotiklot Storage in million $\mathrm{m}^{3}$

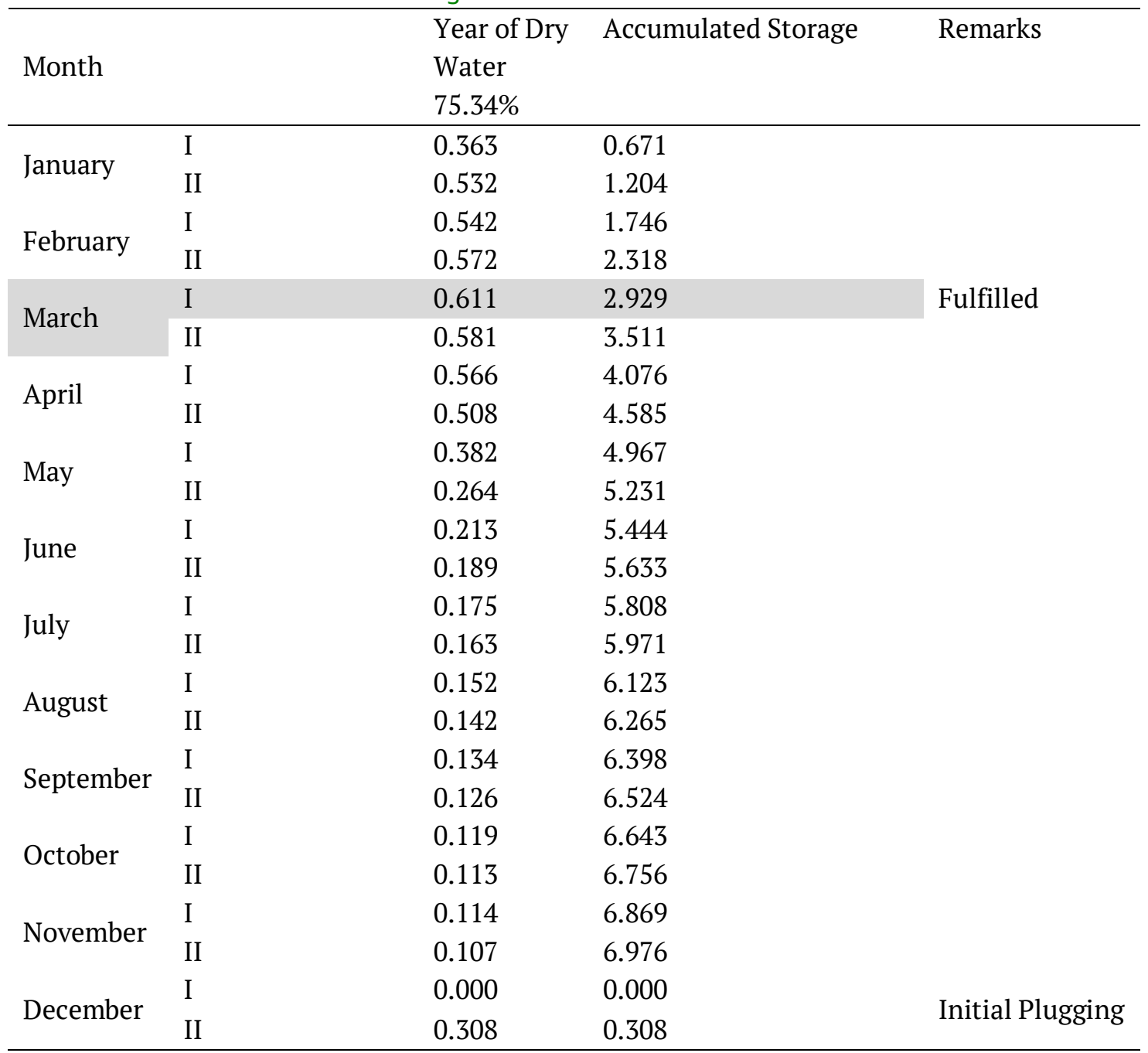




\section{CONCLUSION}

The amount of inflow simulation volume on the Motamuru river calculated using the 4 -series arranged tank model is 21.56 million $\mathrm{m}^{3}$ while the minimum is 2.23 million $\mathrm{m}^{3}$. The average volume inflow of the Rotiklot Reservoir is 10.40 million $\mathrm{m}^{3}$. The probability calculations are divided into four criteria, including the year of a). dry water with the reliability of $97.30 \%$, which is obtained by the annual inflow into the reservoir, amounting to 1.9461 million $\mathrm{m}^{3}$, b). low water with the reliability of $75.34 \%$, obtained by the total inflow into the reservoir annually at 7.2898 million $\mathrm{m}^{3}, \mathrm{c}$ ). normal water with the reliability of $50.68 \%$, obtained by the annual inflow into the reservoir at 9.6991 million $\mathrm{m}^{3}$; and $\mathrm{d}$ ). sufficient water with the reliability of $26.02 \%$. The total inflow into the reservoir per year is 13.8217 million $\mathrm{m}^{3}$. The filling time needed to reach a planned pool of 2.9 million $\mathrm{m}^{3}$ three and a half months, from the middle of December to March. The determination value of $r^{2}$ produced by the tank model composed of 3 -series is 0.506 . The 4 series tank model of the determination value of $r^{2}$ produced is equal to 0.531 . Therefore, based on the determination value of $\mathrm{r}^{2}$ from the two tank models, the 4-series tank model is the most suitable to be used in the Rotiklot Reservoir watershed.

\section{DISCLAIMER}

The authors declare no conflict of interest.

\section{ACKNOWLEDGMENTS}

The author acknowledges with thanks to Balai Wilayah Sungai NT II for the opportunity to complete the data of this research.

\section{REFERENCES}

Amaral and Bilgardo E.D.N.R., 2018. Analisis Pengisian Awal (Impounding) Pada Bendungan Raknamo Dengan Metode Tangki, Kupang: Bachelor Thesis Report. Department of Civil Engineering. Nusa Cendana University.
Badan Pusat Statistik Kabupaten Belu, 2018. Kabupaten Belu dalam Angka Tahun 2017. Jakarta: CV. Nario Sari.

Berlianty, I., and Arifin, M, 2010, Teknik-Teknik Optimasi Heuristik. Yogyakarta: Graha Ilmu.

Kriteria Perencanaan (KP)- 01, 2013. Standar Perencanaan Irigasi -. Jakarta: Kementerian PU

Kuok, K.K., Chiu, P.C., and Harun, S, (2011). Multiobjective Particle Swarm Optimization for optimizing Daily Tank Model's Parameters. Proceeding of ASEAN Australian Engineering Congress, 25th -27th July 2011, Kuching

Ministry of Construction Japan International Cooperation Agency (JICA), 2003. Run-off Calculation Method. References Material for River Engineering Course.

Regulation Number 37 of Indonesia Government Article-1, 2010.

Balai Wilayah Sungai NT II, 2012. Rotiklot Dam Design Note - Hydrology Report. Kupang: Balai Wilayah Sungai NT II.

Setiawan, B.I., and Rudiyanto, 2007. Optimization of Hydrologic Tank Model's Parameters, Umea: Department of Forest Ecology Swedish University of Agricultural Sciences, Umea, Sweden

Silva, M.G., Netto, A.O.A., Neves, R.J.J., Vasco, A.N.V, Almeida, C., and Faccioli, G.G., 2015. Sensitivity Analysis and Calibration of Hydrological Modeling of the Watersheed Northeast Brazil. Journal of Environmental Protection, (68), pp. 837-850.

Sosrodarsono, Suyono., and Kensaku, Takeda., 1980. Hydrology for Irrigation, Jakarta: Pradnya Paramita.

Sugawara, M. and Funiyuki, M., 1956. A Method of Revision of River Discharge by Means of Rainfall Model. Collection of Research Papers about Forecasting Hydrologic Variables, pp. 14-18 . 
Suryoputro and Nugroho., 2018. Calibration of Infiltration Parameters in the Hydrological Tank Model Using Rational Method Runoff Coefficient
Value, Malang: Doctoral Dissertation Report. Department of Civil Engineering. Brawijaya University. 
[This page is intentionally left blank] 